\title{
Research on the Policy and Law of the Insurance of Entrepreneurship--Investment of Undergraduate
}

\author{
Pengfei $\mathrm{Li}^{1, \mathrm{a},}$, , Yanteng Gao', b, Zeping Wang1, c, Wanru Wang ${ }^{2, \mathrm{~d}}$ \\ ${ }^{1}$ Law School, Shanxi University of Finance and Economics, Taiyuan030006, China; \\ ${ }^{2}$ Faculty of finance and Banking, Shanxi University of Finance and Economics, Taiyuan030006, \\ China.
}

a751559067@qq.com, b591513343@qq.com, c1695527932@qq.com, d846940528@qq.com

\begin{abstract}
Under the political guidance and energetically improvements of the policy -- "Mass Entrepreneurship and Innovation" launched by the Central Committee of CCP, there are more and more undergraduates joining in the grass-roots entrepreneurship and they now have been a very significant part of it. However, the complexity of commercial environment, saliency of investment risk and uncertainty of industry interest are becoming more and more no negligible, which leads to greater investment risk for undergraduates when starting their own businesses. On the contrary, the National - Entrepreneurship - Support - System (NESS) are mainly concentrating on the entrepreneurship - convenience - providing but actually neglecting the significance of entrepreneurship - risk- controlling over a long period of time. Therefore, if we can introduce the insurance pattern to the area of entrepreneurship- Investment, and establish the Insurance of Entrepreneurship- Investment of Undergraduate (IEIU) system which will be led by the government, joined by commercial insurance companies and supported by society. Chances are that, only by it can we make up the defect of present entrepreneurship policies in China to some extent.
\end{abstract}

Keywords: Entrepreneurship; policy insurance; undergraduate; investment.

\section{Introduction}

Nowadays, there is a strong atmosphere of "Mass Entrepreneurship and Innovation". Under the guidance and guarantee of the relevant policies and laws, the NESS is also getting more and more perfect. But the specific efforts of the NESS are simply concentrating on the financing preferential and burden relief. Whereas the risk of the entrepreneurship will exist in a long range and the impact of investment risk is becoming more remarkably, but the policies and laws which are devoted to solve these problems are actually absent. Therefore, the effort to control the entrepreneurship risk has become a forgotten element of the NESS. Consequently, whether can we establish a system of IEIU which can impute the risk to insurance company thus helps avoiding the risk of entrepreneurship and dispelling the worries of vast entrepreneurs has becoming a thought-provoking question. IEIU conducted as a government-supporting measure need the lead and overall planning of the government naturally. Furthermore the policy insurance such as agricultural insurance and export credit insurance is the insurance which is founded and supported by government for some political aims. And these insurances are applying the commercial insurance theory and have been already established and administrated by law presently. Therefore, maybe we can draw on the experience of agricultural insurance and export credit insurance's legislative model and bring IEIU into the legislation system, and which may not only helps administrating it but also helps perfecting the NESS to a certain degree. 


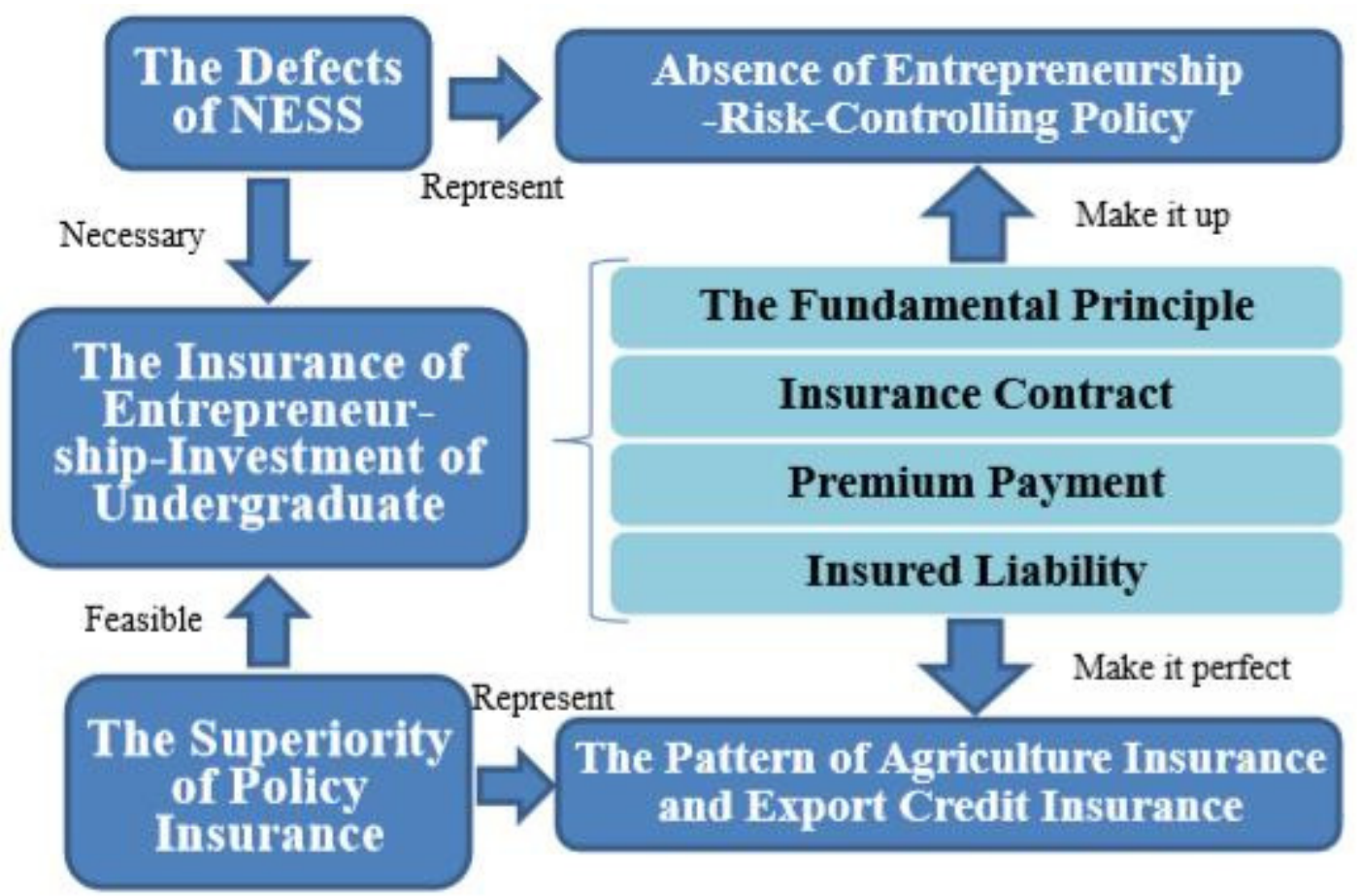

Fig 1. Structure of this article

\section{The Necessity Analysis of IEIU}

\subsection{Analysis of Entrepreneurship-Investment-Risk of Undergraduate}

When it comes to the challenges faced by undergraduate-entrepreneurs in China, there are not only financing difficulties, lack of experience and facility shortage puzzling them, but the entrepreneurship risk is also threatening them all the time. The risk running through the overall process of entrepreneurship, which involves entrepreneurship financing, investment and capital exit. Among which, the main risk faced by undergraduate- entrepreneurs is overall-investment-risk and projectinvestment-risk in the stage of entrepreneurship investment. Overall-investment-risk is that all the funds invested by entrepreneurship-investment companies cause their earnings to be lower than expected due to various reasons. And the project-investment-risk is the risk of loss or gain below expected for a specific investment project[1]. No matter what risk it is, these two risks can all cause the spending more than income for undergraduate- entrepreneurs. But the complexity of commercial environment, saliency of investment risk and uncertainty of industry interest have been enhanced more or less these years, plus the low risk-coping-ability of undergraduate-entrepreneurs, thus, these elements are the arch-criminal of the growth of entrepreneurship-risk. Therefore, how to solve this crisis has been a pressing matter of the moment.

\subsection{Defects of NESS}

The NESS is concentrating on entrepreneurship education, finance and service policy which can be summarized as entrepreneurship-convenience-providing presently[2], but they have ignored the significance of entrepreneurship-risk-controlling actually. Despite the promulgation of State Council's Opinions on Reform and Development of the Insurance Industry in 2006, on which the state council allowed commercial insurance companies to invest the field of entrepreneurship-investment for the first time, and after that, there are more and more new regulations being promulgated constantly. But entrepreneurship is more hazardous after all, commercial insurance companies thus have more apprehensions on whether to provide the insurance and how to make a profit. Besides the premium will be expensive under the commercial insurance pattern, and which beyond the affordable level of the average undergraduate-entrepreneurs. Therefore, the existing products of commercial insurance companies in China are still hard to meet the insurance needs of most undergraduate- 
entrepreneurs. Consequently, it is necessary for us to re-examine the policy of entrepreneurship-riskcontrolling at this stage.

\subsection{The Reference Significance of Policy Insurance}

Policy insurance pattern has many reference significances for entrepreneurship-risk-controlling, which reflects in these three aspects: First and foremost, policy insurance has the function of policy support, on which the support of national policy funds is conducive to eliminating the worries of entrepreneurs and encouraging entrepreneurship. Secondly policy insurance is not based on the principle of profit maximization, its low premium will help relieving the financial burden of the undergraduate-entrepreneurs and expanding the production and operation[3]. Above all, China has already established the policy insurance system and which is now being perfected constantly. Therefore drawing the experience of policy insurance will not only help avoiding the weaknesses of commercial insurance but also help perfecting the policy insurance system. Consequently, in order to make up the defects of entrepreneurship-risk-controlling, it is essential to draw the experience of policy insurance.

\section{The Feasibility Analysis of IEIU}

The reason why we should learn from economic policy insurance instead of social policy insurance when drawing experience from the policy insurance pattern is that: Social policy insurance namely social insurance is highly normative and applied extensively. Social insurance is founded and performed according to Social insurance law of the PRC and its types of insurance are various and it is suitable for all over the society. The establishment and working mode of social insurance are supervised by Social insurance law of the PRC strictly, although which is not belong to the fundamental law of the PRC, the establishment of a new type of social insurance must be implemented by the Standing Committee of the National People's Congress' legal modification as well. However the undergraduate-entrepreneurs group is smaller but less important and more limited than that of the holders of rights of social insurance, and it is difficult, costly and unpractical for us to bring IEIU into social insurance system. Therefore, it is unsuitable to draw experience from the social policy insurance. Furthermore, although the significance of undergraduate-entrepreneurship is not equal to agriculture as well as import and export trade, entrepreneurship is included in obtain employment after all and the latter is a major event related to the national economy and the people's livelihood. And the prosperity of IEIU may provide reference for the entrepreneurship of youth even all society. Consequently, it is a completely reasonable thing for us to establish a new type of economic policy insurance for undergraduate-entrepreneurs. As far as economic policy insurance, there are two major patterns for IEIU to draw experience from:

\subsection{The Agriculture Insurance Pattern}

Agriculture insurance was legislative established by Agricultural Insurance Regulations of the State Council in 2012. And it is controlled by government but its specific businesses are deputed to commercial insurance companies. Then commercial insurance companies such as An Hua Agricultural Insurance Company Ltd will operate the insurance business by commercial insurance pattern and government will give some support and allowance to it. The feature of this pattern is "the guidance of government and the participation of commercial insurance company".

\subsection{The Export Credit Insurance Pattern}

The main patterns of the export credit insurance in the world involves five types, which is the mode of direct management of government agencies, mode of the government wholly owned company, mode of the government's entrustment of a private sector agency, mode of government holding company and mode of joint operation of import and Export Bank[4]. The export credit insurance was legislative established by Notice of the State Council on the Formation of China Export and Credit Insurance Corp in 2001. China Export and Credit Insurance Corp which was founded 
jointly by People's Insurance Company of China as well as the Export-Import Bank of China is a state-holding company. From here we can see that the export credit insurance in China adopts the mode of government holding company.

\section{The Working Hypothesis of IEIU}

According to the analysis above, may as well we can make a hypothesis of IEIU as follows:

\subsection{The Fundamental Principle}

Based on the consideration of practical demand and cost, there are more reference significances on agriculture insurance pattern for us to learn from. So it is suitable for IEIU to draw experience from agriculture insurance. Thus, IEIU should obey the principle of "guidance of government, participation of commercial insurance company and backing of society", which is devoted to the realization of the management of entrepreneurship risk and the elimination of the undergraduateentrepreneurs` apprehension, furthermore, promoting the realization of "mass entrepreneurship and innovation".

\subsection{Insurance Contract}

Our government could set up a special fund to help implementing IEIU, and the university as well as local administration should examine and establish the projects which are expected to be good and highly feasible. After then, it's the duty of government to draft a roster on which some projects are suggested to participate in IEIU. Subsequently, government, social organization as well as commercial insurance company and undergraduate-entrepreneurs enrolled in the roster should sign a contract of IEIU jointly.

\subsection{Premium Payment}

The premium of IEIU should be ascertained by the money which is invested into the entrepreneurship-enterprise. And the premium payment involves three parts: official special fund payment, social fund payment and undergraduate-entrepreneurs ' payment. The contract will come into force from the day it was signed and will be no longer in force until the day which was ascertained anteriorly according to the average year of a certain industries` entrepreneurship. Between these two time points, the premium for the next year will be determined by the entrepreneurs' investment in the previous year. After the ascertainment of the next year's premium, the premium which should be paid by government and social fund shall be remitted to the commercial insurance company's account directly by the end of the year and undergraduate-entrepreneurs should do the same at that time deservedly.

\subsection{Insured Liability}

After the occurrence of insured event, commercial insurance company shall compensate the entrepreneur according to the insurance contract, but the amount of insurance money shall be limited to the total investment amount of the entrepreneur before the insurance accident occurs.

\section{Conclusion}

Therefore, in order to avoid the risk of entrepreneurship, eliminate the apprehension of undergraduate-entrepreneurs and help perfecting the NESS, it is essential for us to do more effort in the aspect of entrepreneurship-risk-controlling. And it plays a constructive role in the activity of perfecting the entrepreneurship-risk-controlling system by drawing experience from policy insurance and building a system of IEIU which is led by the government, joined by commercial insurance companies and supported by society. Consequently, it is necessary to implement and validate it in practice. 


\section{References}

[1]. Kunlun Liu, Jin Wan. Dissertation on the Risk Defusing Function and Development Countermeasures of the Insurance of Entrepreneurship-Investment [J]. Shanghai Insurance, 2012 (08): 46- 49+ 55 .

[2]. Zairian Xu. The Present Situation, Value and Optimization of Supporting Policies for Young Entrepreneurs in China [J]. China Youth Study, 2017 (02): 84-89+77.

[3]. Wei Wang. Tiantian Yang. Lei Liu. Congdi Yue. Dissertation on the Connotation and Extension of Policy Insurance [J]. Financial Theory \& Practice, 2013 (08): 1-5.

[4]. Hua Chen, Wei Hua. International Reference and Comparison of Business Models of Export Credit Insurance [J]. Innovation, 2013, 7(01):49-53. 